\title{
Antenatal Diagnosis of a Case of Pentalogy of Cantrell Associated with Phocomelia
}

\author{
Cantrell Pentaloji ve Fokomelia Birlikteliği Saptanan Olgunun Antenatal Tanısı
}

\author{
Melek Çiçek', Kahraman Ülker', Abdülaziz Gül'1, Kemal Kösemehmetoğlu², Bahattin Balcı ${ }^{3}$ \\ ${ }^{1}$ Department of Obstetric and Gynecology, ${ }^{2}$ Department of Pathology, ${ }^{3}$ Department of Cardiology, Kafkeas University, Kars, Turkey
}

\begin{abstract}
Pentalogy of Cantrell is a rare congenital syndrome; described as the association of partial or complete ectopia cordis, a supraumbilical abdominal wall defect, congenital heart defects, defects in the lower sternum, pericardium, and a deficiency at the anterior diaphragm. In this case, a woman at 20th week of her pregnancy was referred to our clinic with the diagnosis of gastrochisis, however diagnosed with a Cantrell pentalogy associated with a phocomelia of the left upper extremity. Following the termination of the pregnancy postmortem examination confirmed the prenatal diagnosis. To our knowledge, we present the first case of Cantrell Pentalogy associated with phocomelia.
\end{abstract}

Key words: Cantrell pentalogy; phocomelia; pentalogy syndrome; ectopia cordis; abdominal wall defects; diaphram defect; pericardium defect; scoliosis

\section{ÖZET}

Cantrell pentalojisi; kısmi ya da tam ektopia kordis, supraumbilikal karın ön duvar duvar defekti, konjenital kalp defektleri, sternum alt ucu, perikardium ve ön diyafram defektleri birliktelikleri olan ve nadir görülen bir sendromdur. Olgumuzda; gebeliğinin 20. haftasında gastroșizis ön tanısıyla refere edilen bir gebenin fetüsünde Cantrell pentalojisi ve sol üst ekstremitede fokomeli saptanmıștır. Tıbbi tahliye sonrası yapılan post mortem incelemede tanı doğrulanmıștır. Bizim bilgimize göre Cantrell Pentalojisi ile fokomeli birlikteliği olan ilk olguyu sunuyoruz.

Anahtar kelimeler: Cantrell pentalojisi; fokomelia; pentaloji sendromu; ektopik kalp; karın duvarı defekti; diyafram defekti; skolyoz

Melek Cicek, Kafkeas Üniversitesi Tap Fakülttesi, Kadnn Hastahklarn ve Doğum Anabilim Dah, Tel.05068609381Email.dr.mekselina@hotmail.com Gelis Taribi: 05.12.2011 • Kabul Taribi: 16.12.2011

\section{Introduction}

Cantrell Pentalogy, first defined in 1958, includes five described anomalies. These consist of a low set sternum and the defects of the anterior diaphragm, midline supra-umbilical anterior abdominal wall, diaphragmatic pericardium and the intra-cardiac ventricular septum ${ }^{1}$. It is a rare syndrome with an incidence of 55 out of 1.000 .000 live births ${ }^{2}$. Male female distribution is even ${ }^{3}$.

Additional anomalies have been reported in association with Cantrell Pentalogy. Most of the accompanied anomalies were trisomy 13 and 18, Turner syndrome, kyphoscoliosis, clinodactyly, two vessel umbilical cord, fetal ascites and craniofacial anomalies such as cephalocele, cleft palate, cleft lip, micropthalmia and low set ears.

In this paper, we aimed to present a unique case of incomplete Cantrell Pentalogy associated with the phocomelia of the left upper extremity.

\section{Case}

A 26 year-old, parity 2, pregnant woman at the $20^{\text {th }}$ week of her $3^{\text {rd }}$ pregnancy was referred to our department with a suspicion of having a fetus complicated by a gastroschisis. The woman's family history was not remarkable, however four years ago she had a thyroidectomy operation indicated for her goitre and has been using a single daily dose of $100 \mathrm{mcg}$ levo-thyroxine sodium since then. The suspicious fetal anomaly was observed at her first antenatal visit at the $20^{\text {th }}$ week of her current pregnancy.

We performed a detailed ultrasound examination of the pregnancy by using a high resonance ultrasound device (Voluson 730 pro; General 


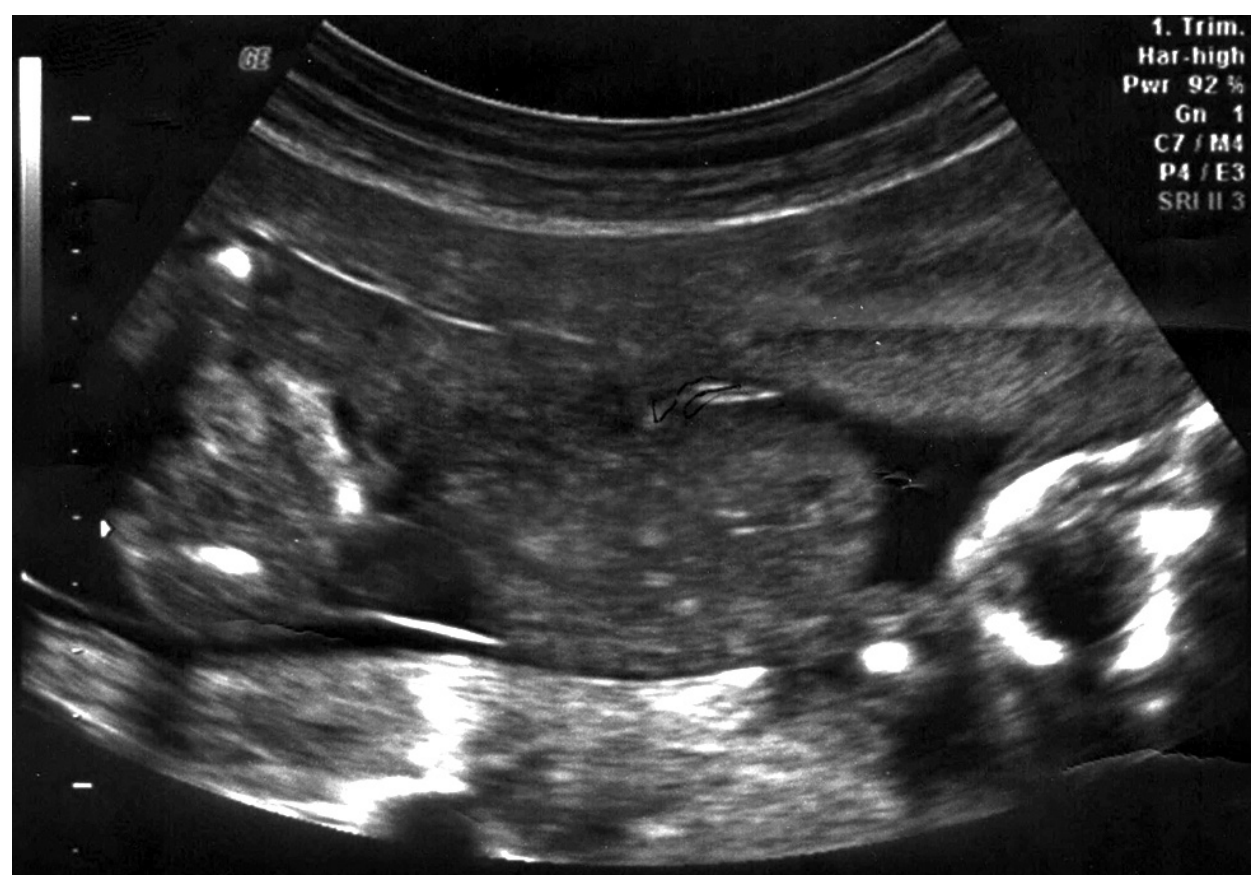

Figure 1. The abdominal organs are freely floating within the amniotic cavity because of the defect in the anterior abdominal wall.

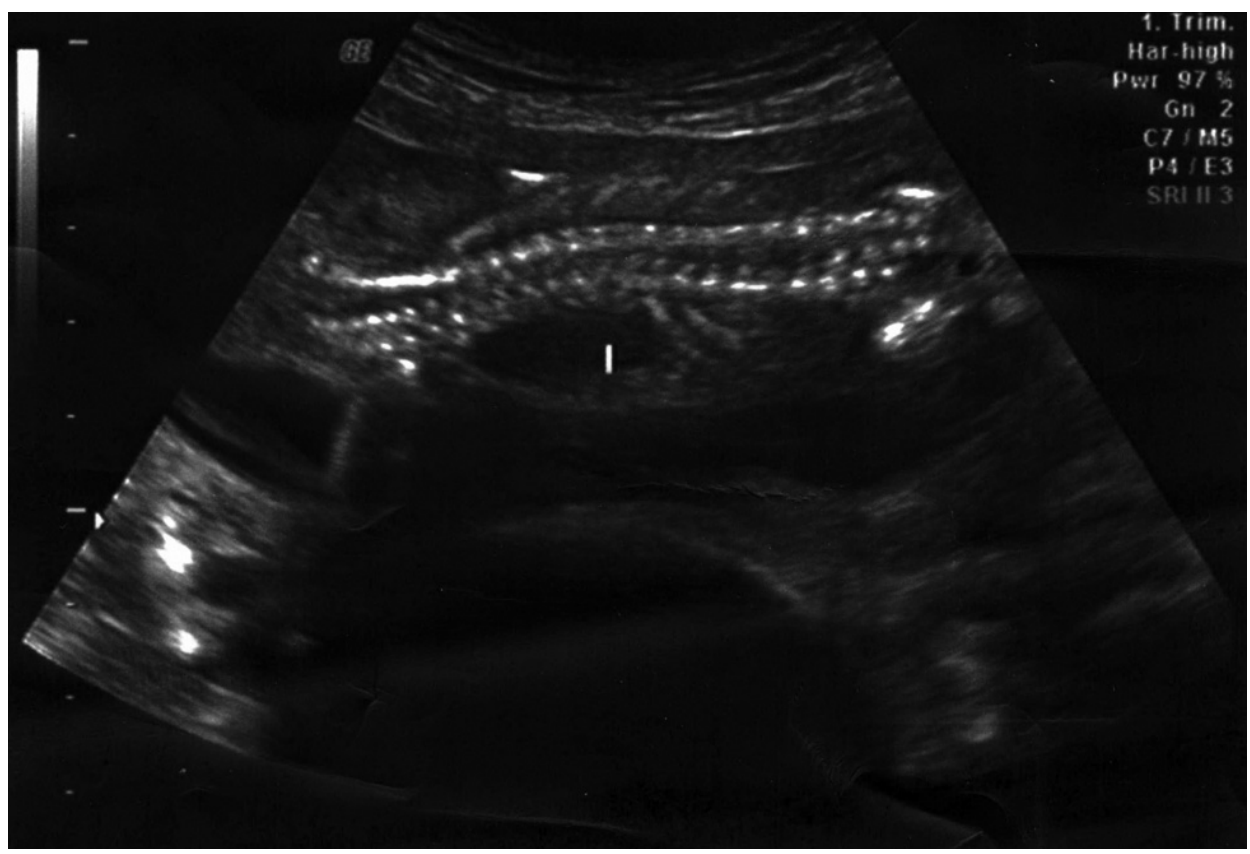

Figure 2. The image of fetal scoliasis identified by the ultrasound.

Electrics-Kretztechnik, Zipf, Austria) equipped with a convex transducer $(2-7 \mathrm{MHz})$. Ultrasound examination revealed a singleton, alive fetus having an average biometric measurement compatible with a 19 weeks and 4 days pregnancy.

Most of the fetal intra abdominal organs including the stomach, liver and intestines were observed outside the abdominal cavity (Figure 1). Fetal heart along with an anterior diaphragmatic defect was directed towards left. Fetal cranial examination revealed a dilatation of the lateral ventricles. During the examination of the fetal vertebral column, an anomalous appearance compatible with scoliosis was noted (Figure 2). Both of the lower extremities and the right upper extremity were visualised without any remarkable finding. However, the left upper extremity could not be visualised. The combination of a wide abdominal wall defect and a 


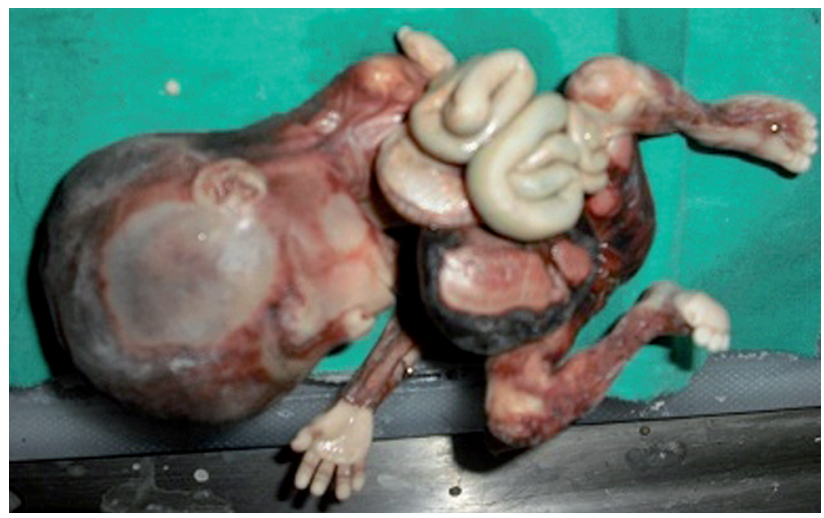

Figure 3. The stomach, liver, spleen and the intestines were protruding outside the abdominal cavity

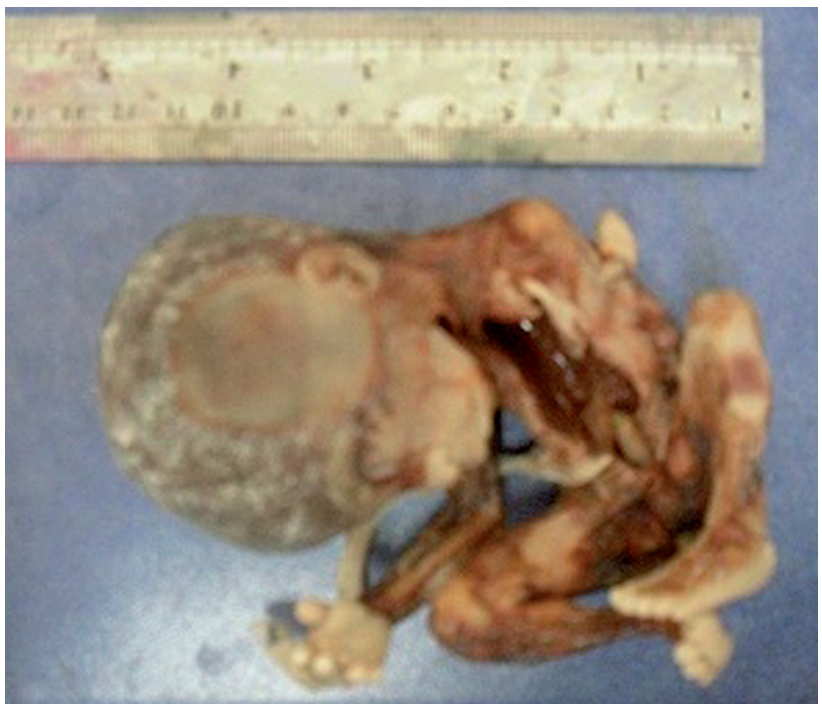

Figure 4. The left arm was stubby with a $5 \mathrm{~mm}$ stem and it was stuck to the chest wall at the level of 4 th costae

diaphragmatic defect that was dislocating the heart towards left led us to the presumptive diagnosis of Pentalogy of Cantrell.

The patient and her family were informed about the prenatal findings and the presumptive diagnosis. In addition a prenatal analysis of the fetal karyotype was offered to the family. However, the family did not accept the work up and decided to terminate the pregnancy. The pregnancy was terminated by the application of vaginal misoprostol.

Macroscopic examination revealed a 140 gram female fetus with the evisceration of most of the gastrointestinal organs. Through a large anterior abdominal wall defect located at the supra umbilical region, the stomach, liver, spleen and the intestines

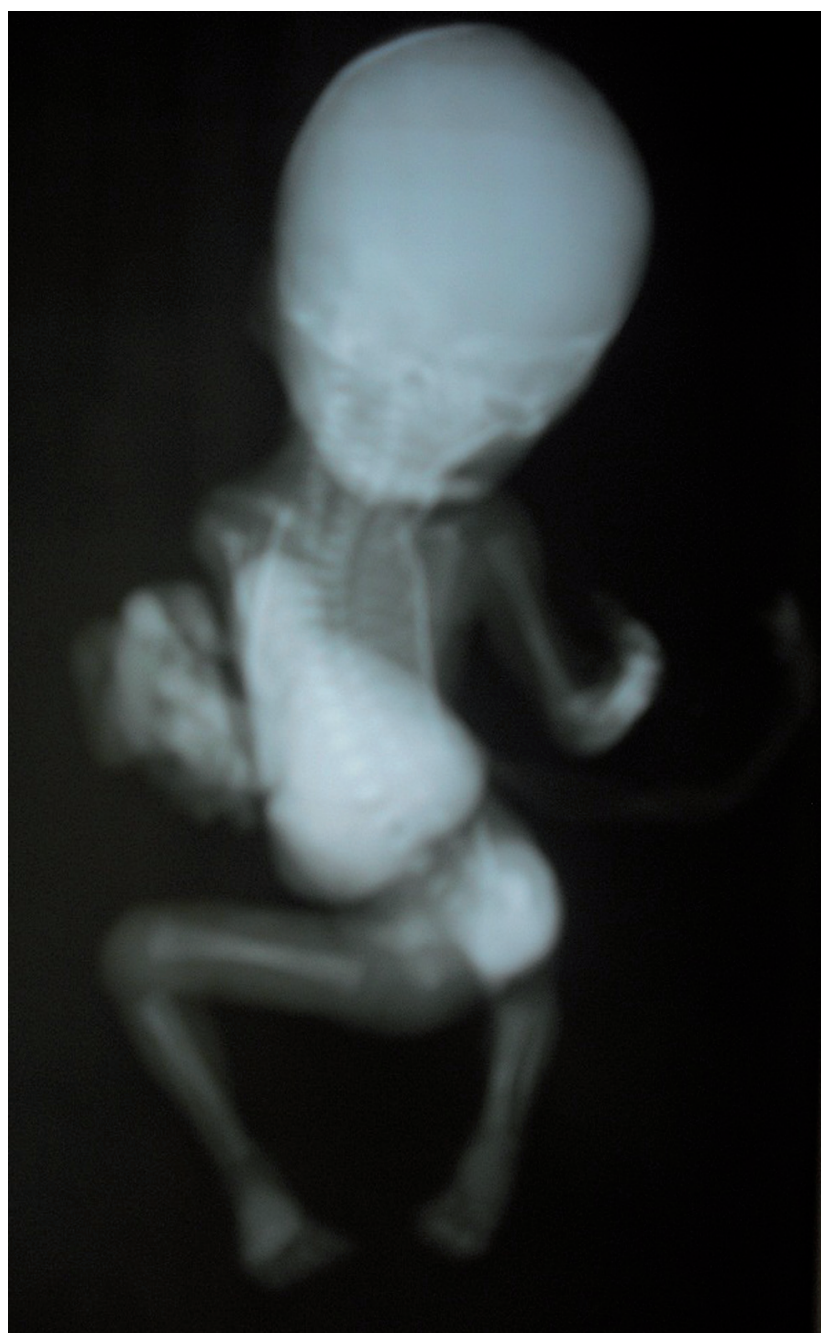

Figure 5. The post abortion X-Ray examination of the anomalies

were protruding outside the abdominal cavity (Figure 3). The left hand and the left forearm were totally absent. The left arm was stubby with a $5 \mathrm{~mm}$ stem and it was stuck to the chest wall at the level of $4^{\text {th }}$ costae (Figure 4). Post abortion X-Ray examination also confirmed the findings (Figure 5).

Pathological macroscopic dissection revealed the hypoplasia of the anterior chest wall and the sternum. The xiphoid process of the sternum, the diaphragmatic muscle and the anterior part of the pericardium were absent (Figure 6). There were hypoplasia of the lungs and a throcal ectopia cordis. In addition to the phocomelia of the left upper extremity, there was a scoliosis of the vertebral colon (Figure 7). 

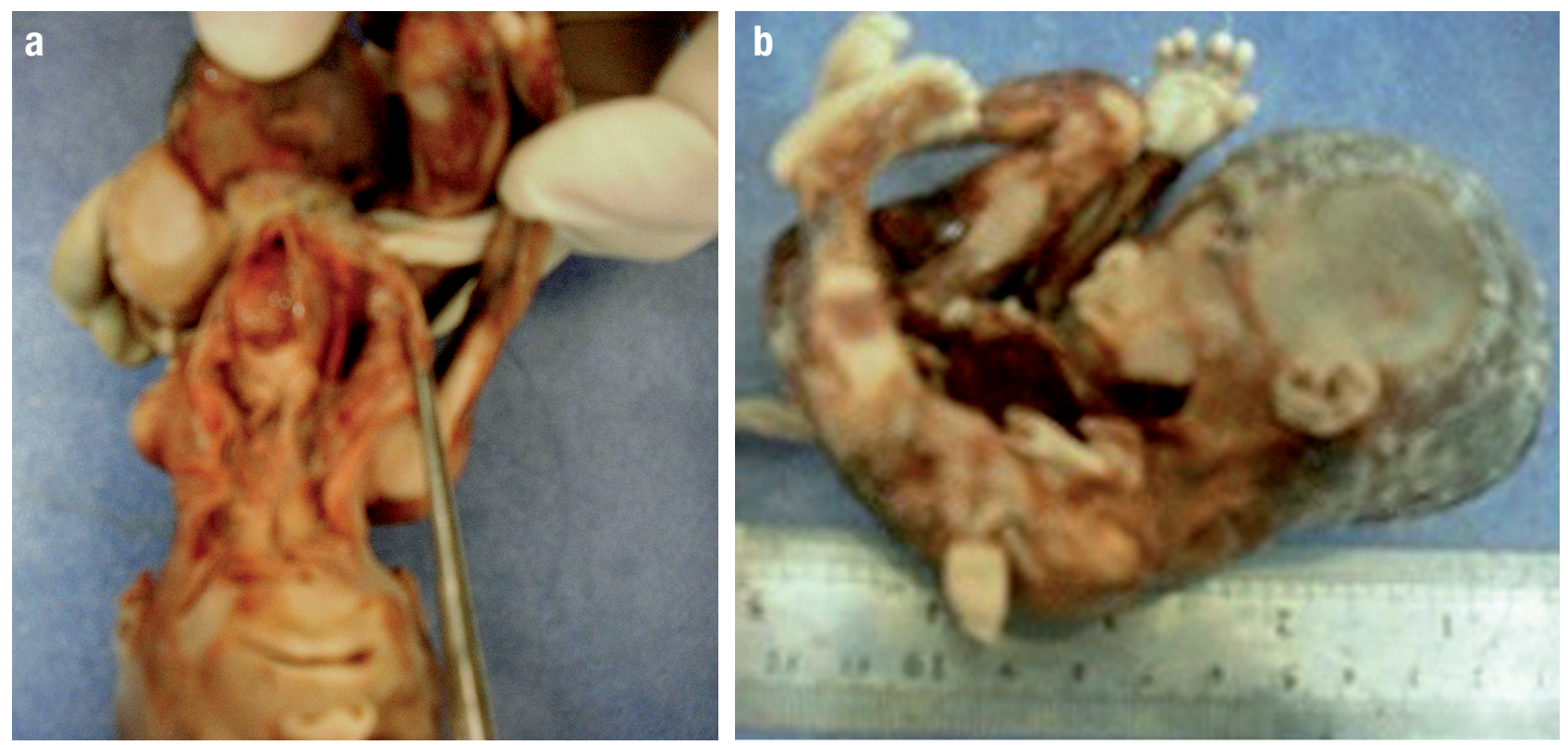

Figure $\mathbf{6} \boldsymbol{a}, \boldsymbol{b}$. The xiphoid process of the sternum, the diaphragmatic muscle and the anterior part of the pericardium were absent.

\section{Discussion}

Cantrell-Haller-Rawitch Syndrome, Pentalogy syndrome, peritoneopericardial diaphragm hernia and throco-abdominal ectopic cordis are other synonyms used for Cantrell Pentalogy ${ }^{4}$. The aetiology of the Pentalogy has not been fully understood yet. It is believed that the defects during migration of the left lateral mesodermal plaque at the 14-18 days of the embryologic development result in the defective formation of the diaphragm, anterior abdominal wall and the thorax.

Toyoma et al, in their study conducted at the end of 1972, suggested a classification of Cantrell Pentalogy into three subclasses. Class 1 consisted of all the 5 defects and the diagnosis was definitive. In class 2 the diagnosis was probable and there were 4 defects including intra cardiac and ventral wall abnormalities. Finally in class 3 the expression was incomplete and it included the combinations of various numbers and degrees of the defects including the sternal abnormality $^{6,7}$.

The most helpful findings of the ultrasound examination are the demonstration of the omphalocele and the ectopic heart. The ectopic heart could be completely out of the thoracic cavity or it may protrude partially out of the weakened sternal tissue $e^{4}$. In our case the apex of the heart partially covered with a semi-transparent membrane was diagnosed

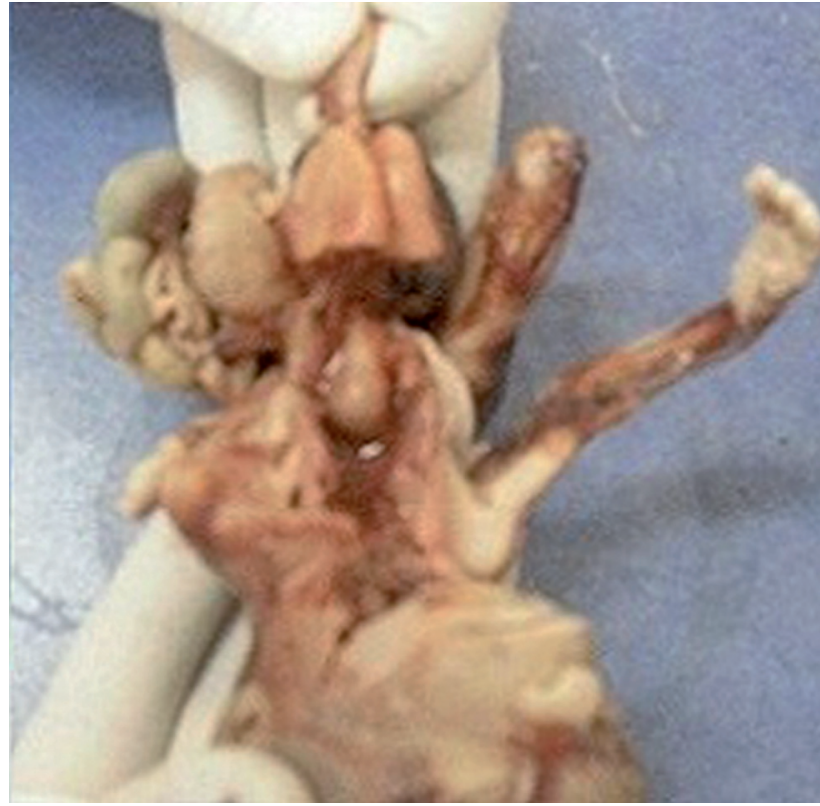

Figure 7. Phocomelia of the left upper extremity

as a partial throcal ectopia cordis. Although we could not find any intra cardiac major anomaly, due to the small fetal age our examination was considered suboptimal. Our case was considered class 2 Cantrell Pentalogy.

The most frequently associated anomalies are atrial septal defect (50\%), ventricular septal defect (VSD) $(20 \%)$ and the tetralogy of Fallot $(10 \%)^{6}$. We could 
not identify any intra cardiac anomaly in either prenatal or postnatal examination. However, in a 23 week fetus diagnosed with an ectopia cordis and a VSD, the pathological examination following the termination of the pregnancy could not reveal any intra cardiac anomaly including the $\mathrm{VSD}^{7}$.

Cantrell Pentalogy was diagnosed in monozygotic twins ${ }^{8}$ and was associated with trisomy $18^{9}$. However, the association with the chromosomal anomalies was rare and in most of the cases the karyotype examinations were normal ${ }^{10,11}$. The diagnosis of Cantrell Pentalogy in two pregnancies of a family raised the suspicions of familial factors in the pathogenesis ${ }^{12}$.

The association of ectopia cordis with gastroschisis was reported in various situations ${ }^{13}$. Cantrell Pentalogy cases published up to date were mostly associated with trisomy13, trisomy18, Turner syndrome, craniofacial anomalies (cephalocele, cleft palate and lip, microphtalmy, and low set ears), kyphoscoliosis, clinodactyly, umbilical cord with two vessels and ascites, 10,14-16. Vertebral deformities like the scoliosis in our case were common.

Association of Cantrell Pentalogy with a limb reduction, phocomelia in our case, has never been published before. The anomaly was probably the result of the local pressure on the limb created by the leftward deviation of the eviscerated abdominal organs.

The earliest diagnosis of Cantrell Pentalogy was at the $12^{\text {th }}$ week of a pregnancy by demonstration of omphalocele and a partial ectopia cordis in the ultrasound examination ${ }^{5}$. Increased nuchal translucency over $2.5 \mathrm{~mm}$ was also helpful in the diagnosis of two other Cantrell Pentalogy cases ${ }^{16,17}$.

Due to its poor postnatal prognosis and high mortality rates, early diagnosis of Cantrell Pentalogy is important, because many parents decide to terminate the pregnancy. First trimester scanning including nuchal fold thickness measurement increases the chance of diagnosis of chromosomal and heart anomalies, thus increases the chance of early diagnosis of Cantrell Pentalogy. The association of a nuchal fold thickness over $2.5 \mathrm{~mm}$ with an anterior abdominal wall defect like an omphalocele or a gastroschisis mandates to rule out the diagnosis of Cantrell Pentalogy.

\section{References}

1. Cantrell JR, Haller JA, Ravitch MM. A Syndrome of congenital defects involving the abdominal wall, sternum, diaphragm, pericardium and heart. Surg Gynecol Obstet 1958; 107:60214.

2. Carmi R, Boughman JA. Pentalogy of Cantrell and associated midline anomalies: a possible ventral midline developmental field. Am J Med Genet 1992; 42:90-5.

3. Desselle C, Herve P, Toutain A, et al. Pentalogy of Cantrell: sonographic assessment. J Clin ultrasound 2007; 35:216-20.

4. Gonçalves LF, Jeanty P. Ultrasonographic diagnosis of fetal abdominal wall defects. In: Callen PW (Editor). Callen's Ultrasonography in Obstetrics and Gynecology. Philadelphia: WB Saunders; 1997: 432-3.

5. Eberhard Merz. Ultrasonographic diagnosis of fetal anomalies. Cantrell Pentalogy. In: Ultrasonography in Obstetrics and Gynecology. New York: McGraw- Hill; 2009.

6. Toyama WM. Combined congenital defects of the anterior abdominal wall, sternum, diaphragm, pericardium and heart: a case report and review of the syndrome. Pediatrics 1972; 50:778-92.

7. Van Hoorn JHL, Moonen RMJ, Huysentruyt CJR, et al. Pentalogy of Cantrell: two patients and a review to determine prognostic factors for optimal approach. Eur J Pediatr 2008; 167: 29-35.

8. Baker ME, Rosenberg ER, Trofatter KF, et al. The in utero findings in twin pentalogy of Cantrell. J Ultrasound Med 1984; 3:525-7.

9. Correa-Rivas MS, Matos-Llovet I, García-Fragoso L. Pentalogy of Cantrell: a case report with pathologic findings. Pediatr Dev Pathol 2004; 7: 649-52.

10. Uludağ S, Barbaros ZM, Aksoy F, et al. Cantrell Syndrome: A case Report. Perinatal Journal 1999; 7: 324-7.

11. Küçük M, Sezer SD, Yüksel H, et al. A prenatally diagnosed pentalogy of Cantrell Case. Pamukkale Medical Journal 2010; 3: 161-3.

12. Martin RA, Cunniff C, Erickson L, et al. Pentalogy of Cantrell and ectopia cordis, a familial developmental field complex. Am J Med Genet 1992; 42:838-41.

13. Tibboel D, Raine P, McNee M, et al. Developmental aspects of gastroschisis. J Pediatr Surg 1986; 21: 865-9.

14. Ghidini A, Sirtori M, Romero R, et al: Prenatal diagnosis of Pentalogy of Cantrell. J Ultrasound Med 1988; 7:567-72.

15. Fox JE, Gloster ES, Mirchandani R. Trisomy 18 with Cantrell Pentalogy in a stilborn infant Am J Med Genet 1988; 31:39-4.

16. Markov D, Chernev T, Dimitrova V, et al. Pentalogy of Cantrell associated with increased nuchal translucency at 12+1 w.g. Case Report. Akush Ginekol 2004; 43:34-6.

17. Staboulidou I, Wüstemann M, Schmidt P, et al. Increased fetal nuchal translucency as a predictor of Cantrell's Pentalogy: case report. Z Geburtshilfe Neonatol 2005; 209:231-4. 